\title{
WZBUDZANIE EMOCJI \\ SAMOŚWIADOMOŚCIOWYCH JAKO STRATEGIA WYKORZYSTYWANA PRZEZ RODZICÓW DOROSEYCH DZIECI UZALEŻNIONYCH OD ALKOHOLU DO WYWOLYWANIA U NICH ZAMIANY ZACHOWANIA
}

\begin{abstract}
Streszczenie
Celem artykutu jest przedstawienie jednej ze strategii wykorzystywanych przez rodziców do zaprzestania picia u ich dorostych dzieci. Strategia ta opiera się na wzbudzaniu emocji samoświadomościowych. Do zilustrowania poruszonej problematyki wykorzystano wywiady swobodne i pogłębione przeprowadzone $z$ rodzicami dorostych dzieci z problemem alkoholowym. W oparciu o analize uzyskanego materiału okazało się, że emocje takie jak wstyd i poczucie winy sa powszechnie wykorzystywane $w$ relacjach rodziców z ich dorostymi pijacymi dziećmi. Wzbudzanie takich emocji ma na celu stymulowanie do zaprzestania picia i przestrzegania norm społecznych. Jednak nie wszystkie emocje, z perspektywy rodziców, sprzyjaja zmianie zachowania.
\end{abstract}

Słowa kluczowe: uzależnienie od alkoholu, emocje samoświadomościowe, wstyd, poczucie winy, rodzice dorostych dzieci uzależnionych od alkoholu

\section{Wstęp}

Analiza piśmiennictwa naukowego (rodzimego, jaki i anglojęzycznego) poświęconego rodzinom osób uzależnionych od alkoholu uwidacznia dwa obszary,

* Mgr Agnieszka Jaros - pedagog, Wydział Nauk o Wychowaniu, Pracownia Pedagogiki Specjalnej, Uniwersytet Łódzki. 
na których skoncentrowana jest uwaga naukowców, tj. doświadczenia dzieci wychowywanych w rodzinach z problemem alkoholowym (szczególnie dorosłych) oraz małżonków/partnerów osób uzależnionych. Liczne badania, w których analizowane są doświadczenia dzieci z rodzin z problemem uzależnienia od alkoholu koncentrują się przede wszystkim na wpływie uzależnienia i konfliktów między rodzicami na ich rozwój'; identyfikacji cech osobowościowych i uwarunkowań genetyczne, które predestynują dzieci do rozwoju uzależnienia lub zaburzeń psychicznych (np. zaburzenia odżywiania) ${ }^{2}$. Drugi obszar badań poświęcony partnerom/małżonkom osób uzależnionych skupia się również na identyfikacji ich cech osobowości sprzyjających współuzależnieniu ${ }^{3}$ oraz skuteczności oddziaływań terapeutycznych, którym są poddawane $e^{4}$.

R. Szczepanik i K. Okólska ${ }^{5}$ dokonując przeglądu literatury poświęconej tej problematyce, zwróciły uwagę na brak opracowań naukowych o rodzicach dorosłych osób uzależnionych od alkoholu. Obszar ten, zdaniem badaczek, jest zaniedbany a specyficzne doświadczenia rodziców dorosłych dzieci uzależnionych od alkoholu nie znajdują odrębnego miejsca w dyskursie naukowym.

Nawiązując do powyższego poglądu Szczepanik i Okólskiej zespół z Pracowni Pedagogiki Specjalnej, Wydziału Nauk o Wychowaniu, Uniwersytetu Łódzkiego,

1 Por. T. M. Knudson, H. K. Terrell, Codependency, Perceived Interparental Conflict, and Substance Abuse in the Family of Origin, „The American Journal of Family Therapy” 2012, nr 40, s. 245-257.

2 Por. A. Cur, K. Szymona, M. Domański, A. Opolska, M. Jojczuk, Parentalalcoholabuse and eatingbehaviors in adolescents, ,Polish Journal of Public Health” 2015, nr 125(4), s. 194196; I. R. Gizer, C. L. Ehlers, C. Vietend, K. L. Seaton-Smithe, H. S. Feiler, J. V. Lee, S. K. Segall, D. A. Gilder, K. C. Wilhelmsen, Linkagescan of alcoholdependence in the UCSF Family Alcoholism Study, „Drug and Alcohol Dependence” 2011, nr 113, s. 125-132; I. R. Gizer, K. L. Seaton-Smithe, C. L. Ehlers, C. Vietend, K. C. Wilhelmsen, Heritability of MMPI-2 Scales in the UCSF Family Alcoholism Study, ,Journal of Addictive Diseases” 2010, nr 29 (1), s. 84-97.

3 Por. L. Panaghi, Z. Ahmadabadi, N. Khosravi, M.S. Sadeghi, A. Madanipour, Living with Addicted Men and Codependency: The Moderating Effect of Personality Traits, „Addict Health" 2016, nr 8(2), s. 98-106.

4 Por. J. Orford, L. Templeton, A. Patel, A. Copello, R. Velleman, The 5-Step family intervention in primary care: I. Strengths and limitations according to family members, „Drugs: education, prevention and policy” 2007, nr 14 (1), s. 29-47.

5 Por. R. Szczepanik, K. Okólska, Zapomniani rodzice (dorosłych) dzieci uzależnionych od alkoholu, „Alkoholizm i Narkomania” 2018, nr 31(4), s. 273-300. 
opracował projekt naukowy ${ }^{6}$, którego celem jest wypełnienie obszaru naukowej „niewiedzy” dotyczącego dominujących problemów i potrzeb rodziców dorosłych dzieci uzależnionych od alkoholu oraz ich roli jaką odgrywają w procesie zdrowienia swojego dziecka.

Materiał zaprezentowany przez autorkę artykułu stanowi fragment zrealizowanych badań w ramach tego projektu i poświęcony jest jednej ze strategii zaradczej wykorzystywanej przez rodziców dorosłych dzieci uzależnionych od alkoholu, jaką jest wzbudzanie emocji samoświadomościowych.

Rodzice dorosłych dzieci z problemem alkoholowym stawiają sobie często trudne zadanie zmiany zachowania dorosłego już dziecka (tj. zaprzestania picia). W tym celu korzystają z różnych dostępnych form pomocy zarówno formalnej, jak i nieformalnej. Chcąc uzyskać zmianę, wykorzystują szereg strategii zaradczych, mających z ich perspektywy doprowadzić do zaprzestania nałogowego zachowania swoich dzieci. Izolują je od czynników sprzyjających piciu, organizują minimalną stabilizację, by zatrzymać degradację dziecka. Tłumaczą, proszą, pilnują swoje dzieci. Jedną ze strategii jest także wzbudzanie u nich emocji samoświadomościowych (takich jak zażenowanie, wstyd czy poczucie winy), które uczyniono przedmiotem niniejszego artykułu.

Na początku artykułu przedstawiona zostanie teoria poznawczo-atrybucyjna Lewisa, którą uczyniono podstawą teoretyczną dalszych analiz. Następnie opisane będą definicje emocji samoświadomościowych, omówiony zostanie aspekt psychologiczny w rozwoju uzależnienia oraz metodologia przeprowadzonych badań. Na zakończenie przedstawione zostaną wyniki dotyczące skuteczności podejmowanych oddziaływań z punktu widzenia rodziców dorosłych dzieci uzależnionych od alkoholu.

\section{Teoria poznawczo-atrybucyjna}

Zgodnie z teorią poznawczo-atrybucyjną elementy poznawcze mogą wywoływać emocje, jak i emocje mogą prowadzić do powstawania elementów poznawczych?7.

\footnotetext{
6 Projekt naukowy nt. „Rodzina w systemie wsparcia społecznego i pomocy osobom z problemem alkoholowym. Badania biograficzne z udziałem rodziców (dorosłych) dzieci uzależnionych od alkoholu”, i realizowany jest w ramach zadania „Wspieranie badań naukowych w obszarze problemów wynikających z używania alkoholu”. Projekt ten realizowany jest ze środków Funduszu Rozwiązywania Problemów Hazardowych w ramach Narodowego Programu Zdrowia na lata 2016-2020.

7 Por. M. Lewis, Emocje samoświadomościowe: zażenowanie, duma, wstyd, poczucie winy, w: Psychologia emocji, red. M. Lewis, J. M. Haviland-Jones, GWP, Gdańsk 2005,
} s.784. 
Wychowując się w określonej kulturze, człowiek przyswaja sobie zbiór przekonań (norm, zasad, celów), które stanowią informację nabywaną przez jednostkę pod wpływem oddziaływań kultury danego społeczeństwa. Chcąc stać się członkami określonej grupy, musimy przyswoić sobie określony zbiór przekonań. Już od pierwszego roku życia dziecko uczy się wzorów właściwych zachowań, a w drugim roku wykazuje pewne zrozumienie czym jest właściwe zachowanie. Należy jednak zauważyć, że nabywanie norm, zasad i celów trwa przez całe życie człowieka ${ }^{8}$. Ocena czyichś czynów, myśli czy uczuć w odniesieniu do zbiorów przekonań (norm, zasad, celów) jest procesem poznawczo - ewaluacyjnym wywołującym emocje samoświadomościowe. Ocena taka może mieś charakter wewnętrzny lub zewnętrzny. Dokonując oceny wewnętrznej, jednostka w odniesieniu do norm, zasad czy celów dane zachowanie określa jako sukces lub porażkę. Dokonuje także atrybucji odnoszącej się do Ja. Może mieć ona charakter całościowych lub szczegółowych autoatrybucji ${ }^{9}$. Zgodnie z teorią poznawczo-atrybucyjną, biorąc pod uwagę te trzy grupy czynników (normy, zasady i cele, ocenę działań jako sukces lub porażkę oraz dokonaną autoatrybucję) można wyjaśnić, jak te czynniki wpływają na powstawanie niektórych emocji samoświadomościowych ${ }^{10}$.

\section{Emocje samoświadomościowe}

Jednym z podstawowych założeń strukturalnego modelu definiowania emocji samoświadomościowych jest to, że emocjom nadany jest taki sam status jak poznaniu. W modelu wyróżniono cztery stany emocjonalne takie jak: wstyd, poczucie winy, pycha i duma. Wstyd, zgodnie z tym modelem, wynika z niepowodzenia w stosunku do norm, zasad i celów, gdy osoba dokonuje całościowej oceny Ja. Poczucie winy jest wynikiem ocenienia działania jako porażki, ale autoatrybucja ma charakter szczegółowy. Analogicznie powstaje emocja zwana dumą. Jednostka swoje działania (w odniesieniu do norm, zasad i celów) ocenia jako sukces i dokonuje szczegółowej autoatrybucji. Natomiast pycha jest konsekwencją sukcesu i całościowej oceny $\mathrm{Ja}^{11}$. Wśród emocji samoświadomosciowych M. Lewis wymienił także zażenowanie (definiowane jako mniej intensywny wstyd, wynikający z mniejszego znaczenia dla jednostki naruszonych norm). Jako że emocje takie jak wstyd i poczucie winy mogą pojawiać się w sytuacji zawstydzania (a jest to

\footnotetext{
8 Tamże, s. 785.

9 Por. M. E. P. Seligman, Optymizmu można się nauczyć. Jak zmienić swoje myślenie i swoje życie, Media Rodzina of Poznań, Poznań 1990, s. 72-84.

10 Por. M. Lewis, Emocje samoświadomościowe... dz. cyt., s. 787.

11 Tamże, s. 787.
} 
strategia bardzo często wykorzystywana przez rodziców dorosłych dzieci uzależnionych od alkoholu) warto podkreślić podstawowe różnice między tymi emocjami. Wstyd jest emocją skłaniającą jednostkę do ukrycia się, zniknięcia lub śmierci. Jest to stan bardzo negatywny, powodujący całościowy zamach na system Ja. Osoba odczuwająca wstyd czuje, że w jakiś istotny sposób jest nie taka, jak powinna być (jako człowiek jest gorsza) ${ }^{12}$. Poczucie winy jest emocją powstającą wtedy, kiedy osoba ocenia swoje zachowanie jako porażkę, ale jej uwaga skierowana jest na konkretne cechy lub działania, które doprowadziły do tego niepowodzenia. Konsekwencją poczucia winy są działania naprawcze, jakie może podjąć osoba ją odczuwająca (choć nie zawsze je podejmuje). Intensywność poczucia winy jest mniejsza niż intensywność wstydu, dlatego łatwiej jest się jej pozbyćc $c^{13}$.Warto także przywołać sposób definiowania dumy przez M. Lewisa jako, doświadczenia radości spowodowanej udanymi działaniami, myślami lub uczuciami. Duma jest taką emocją samoświadomościową, w której uwaga jest określona i dotyczy konkretnego zachowania, a Ja pozostaje oddzielone od przedmiotu działania ${ }^{14}$.

\section{Uzależnienie jako „choroba emocji”}

Badacze zajmującysz się problematyką uzależnień są zgodni co do tego, że uzależnienie ma wieloczynnikowe uwarunkowania. Wzajemne przenikanie się czynników biologicznych, społecznych, psychologicznych i duchowych, wymaga holistycznego podejścia w procesie leczenia uzależnień i zajmowania się każdą $\mathrm{z}$ wymienionych $\operatorname{sfer}^{15}$. Aspekt psychologiczny w rozwoju i powrocie do uzależnienia odgrywa na tyle ważną rolę, że pomimo braków objawów biologicznych (np. zniesionych/zwalczonych podczas detoksykacji), osoby powracają do nałogu. Pośród czynników psychologicznych, które sprzyjają rozwojowi uzależnienia wymienia się m. in.: niedojrzałość emocjonalną, małą odporność na frustrację, nieumiejętność wyrażania emocji, wysoki poziom niepokoju w relacjach interpersonalnych, niskie poczucie własnej wartości i skuteczności, zmienny stosunek do

12 Por. M. Lewis, Emocje samoświadomościowe... dz. cyt., s. 787; A. Dodziuk, Wstyd, Instytut Psychologii Zdrowia, PTP, Warszawa 1999, s. 11.

13 Por. tamże, s. 788; tamże, s. 11.

14 Por. M. Lewis, Emocje samoświadomościowe... dz. cyt., s.789, w: Psychologia emocji, red. M. Lewis, J.M. Haviland-Jones, s. 780-797, GWP, Gdańsk.

$15 \mathrm{Z}$ racji poruszanej problematyki $\mathrm{w}$ tym artykule, zostanie omówiony tylko aspekt psychologiczny. 
autorytetów, poczucie winy ${ }^{16}$. Wśród osób uzależnionych od alkoholu, utrzymujących abstynencję chęć napicia się może być spowodowana m. in. czynnikami zewnętrznymi takimi jak: nagłe przykre wydarzenie, silna ekspozycja na działanie bodźca czy chwilowe wahanie nastroju ${ }^{17}$. Czynniki te są trudne do badania, ale jednocześnie aspekt emocjonalny osoby uzależnionej niewątpliwie odgrywa bardzo ważną rolę w utrzymywaniu się uzależnienia, jak i powrotach do zachowań związanych z piciem alkoholu po okresie abstynencji. Próbując wyjaśnić psychologiczne powody sięgania po alkohol, naukowcy sprawdzali różne hipotezy m. in. hipotezę redukcji napięcia, hipotezę „wytłumienia odpowiedzi stresowej”. Okazało się, że alkohol u osób zażywających go może zmniejszać napięcie emocjonalne, przynosić w chwilach doświadczania stresu ulgę, jak również może stać się jedynym źródłem osiągania pozytywnych stanów emocjonalnych ${ }^{18}$. W wyniku długotrwałego picia alkoholu, dochodzi do rozwoju u osoby pijącej psychopatologicznych mechanizmów uzależnienia t.j. mechanizm nałogowego regulowania uczuć, mechanizm iluzji i zaprzeczania oraz mechanizm rozdwajania i rozpraszania $\mathrm{JA}^{19}$. Mechanizmy te działają na szkodę osoby pijącej, tworząc wewnętrzną, destrukcyjnie zaprogramowaną strukturę kierującą osobę uzależnioną w stronę przedwczesnej śmierci. Osoby uzależnione od alkoholu zazwyczaj negują swoje uzależnienie, obawiają się rozstania z alkoholem i aktywnie bronią przed leczeniem. Oferta terapeutyczna dla takich osób jest przygotowywana w specjalny sposób. Przebiega zazwyczaj na pięciu etapach, gdzie pierwszy stanowi etap rozpoczęcia procesu zdrowienia, drugi koncentruje się na uznaniu własnego uzależnienia i powstrzymywaniu się od picia, trzeci etap poświęcony jest rozbrajaniu psychopatologicznych mechanizmów uzależnienia i zapobieganiu nawrotom, a kolejne zmianie zachowań i sytuacji społecznych klienta oraz rozwiązywaniu problemów osobistych ${ }^{20}$. Praca nad psychopatologicznymi mechanizmami uzależnienie nie bez przyczyny znalazła się

16 Por. J. Chodkiewicz., Rola zasobów osobistych $w$ utrzymaniu abstynencji przez mężczyzn uzależnionych od alkoholu, „Alkoholizm i Narkomania” 2001, t. 14, s. 277-287; J. G. Woititz, Matżeństwo na lodzie. Psychologiczne problemy żon alkoholików, IPZiT, Warszawa 1989, s. 6-13.

17 Cyt. za J. Chodkiewicz., Rola zasobów osobistych w utrzymaniu abstynencji przez mężczyzn uzależnionych od alkoholu, dz. cyt., s. 278.

18 Por. B. T Woronowicz, Uzależnienia. Geneza, terapia, powrót do zdrowia, Media Rodzina, PARPAMEDIA, Warszawa, Poznań 2009, s. 71-72; L. Cierpiałkowska, M. Ziarko, Psychologia uzależnień - alkoholizm, Wydawnictwo Akademickie i Profesjonalne Spółka z o.o., Warszawa 2010, s. 148-155.

19 Por. J. Mellibruda, Strategiczno-strukturalna psychoterapia uzależnień, „Alkoholizm i Narkomania" 1997, t. 3, s. 307-324.

20 Tamże, s. 309-310. 
na trzecim etapie pracy terapeutycznej. Uzdrawianie życia emocjonalnego osoby uzależnionej od alkoholu wymaga zmiany mechanizmu nałogowego regulowania uczuć i wypracowania skutecznych sposobów radzenia sobie z negatywnymi stanami emocjonalnymi. Praca terapeutyczna skupia się przede wszystkim na nauce rozpoznawania uczuć, kontaktowaniu się z bolesnymi uczuciami i oswajaniu ich obecności, zwiększaniu odporności na cierpienie i zdolności do radzenia sobie ze stresem oraz uczeniu się zdrowych sposobów doświadczania pozytywnych emocji.W pracy terapeutycznej klienci bardzo szybko doświadczają silnych stanów emocjonalnych tj. gniew, lęk, smutek, poczucie wstydu czy winy. Należy jednak wykazać się powściągliwością w pracy z emocjami na tym etapie, gdyż na ogół klienci nie dysponują zdolnością do poradzenia sobie z ciężarem głębokiej pracy nad bolesnymi stanami emocjonalnymi. Podjęcie takiej pracy może niestety doprowadzić do dezintegracji psychicznej klienta i uruchomić mechanizmy uzależnienia, co skutkuje powrotem do picia ${ }^{21}$.

\section{Założenia teoretyczno-metodologiczne}

Perspektywą poznawczą w prowadzonych badaniach uczyniono paradygmat interpretatywny i metodologię badań jakościowych ${ }^{22}$. Ontologiczne przesłanki ujmowania rzeczywistości społecznej rodziców dorosłych dzieci uzależnionych od alkoholu zaczerpnięto $\mathrm{z}$ teorii symbolicznego interakcjonizmu ${ }^{23}$. Zaprezentowany w artykule materiał empiryczny stanowi fragment szerszych badań nad rodziną w systemie wsparcia społecznego i pomocy osobom z problemem alkoholowym. W badaniach, które realizowane są w latach 2018-2020 uczestniczą rodzice (ojcowie i matki) dorosłych dzieci z problemem alkoholowym i pracownicy instytucji związanych z pomocą rodzinom z problemem uzależnienia od alkoholu (m.in. lekarze, terapeuci, pracownicy socjalni, kuratorzy, księżą, itp.). Zgodnie z założeniami teorii ugruntowanej ${ }^{24}$ materiał empiryczny poddawany jest systematycznej analizie i wyprowadzane są z niego kategorie teoretyczne. W ramach realizowanego

21 Por. J. Mellibruda, Z.Sobolewska-Mellibruda, Integracyjna psychoterapia uzależnień. Teoria i praktyka, Instytut Psychologii Zdrowia, Polskie Towarzystwo Psychologiczne, Warszawa 2006.

22 Por. K. Rubacha, Metodologia badań nad edukacją, Wydawnictwa Akademickie i Profesjonalne, Warszawa 2008; D. Urbaniak-Zając, E. Kos, Badania jakościowe w pedagogice, Wydawnictwo Naukowe PWN, Warszawa 2013.

23 Por. E. Hałas, Interakcjonizm symboliczny, Wydawnictwo Naukowe PWN, Warszawa 2012.

24 Por. K. Konecki, Studia z metodologii badań jakościowych. Teoria ugruntowana, Wydawnictwo Naukowe PWN, Warszawa 2000. 
projektu, przeprowadzono dotychczas kilkanaście wywiadów z rodzicami. W trakcie grupowej analizy materiału empirycznego wyodrębniono kategorię teoretyczną jaką jest wzbudzanie emocji samoświadomościowych. Celem badań uczyniono prześledzenie i zrozumienie strategii oddziaływania rodzicielskiego polegającej na wzbudzaniu emocji samoświadomościowych u swoich dzieci, aby doprowadzić do zmiany jego zachowania (czyli zaprzestanie picia). W związku z tym postawiono następujące pytania badawcze:

1. Jakie emocje samoświadomościowe wzbudzają rodzice u swoich dorosłych dzieci uzależnionych od alkoholu?

2. Jaka jest skuteczność strategii zaradczej polegającej na wzbudzaniu emocji samoświadomościowych, mającej na celu zmianę zachowania dorosłych dzieci (zaprzestanie picia) z perspektywy rodziców?

W badaniach wykorzystano metodę teorii ugruntowanej, natomiast techniką pozyskiwania danych uczyniono wywiady swobodne i pogłębione (z elementami wywiadu narracyjnego ${ }^{25}$. Metodyka prowadzenia wywiadu umożliwia prześledzenie nie tylko doświadczeń życiowych badanych, ale także różnego rodzaju ich przemiany np. stanów uczuciowych. Zastosowanie opisanej techniki pozwala na zebranie danych o szczególnie trudnych doświadczeniach życiowych, ponieważ to od osoby badanej zależy, jakie wątki poruszy, a także w jaki sposób je rozwinie. Zadaniem badacza jest przede wszystkim stworzenie warunków do swobodnej narracji. Respondenci sami decydowali o terminie i miejscu spotkania. Osoby prowadzące wywiady starały się stworzyć przyjazną atmosferę i wzbudzić zaufanie respondentów. Każdemu uczestnikowi badań został przedstawiony cel, przedmiot i charakter badań. Respondenci wyrazili zgodę na nagrywanie wywiadu, jego transkrypcję i wykorzystanie uzyskanego materiału do celów badawczych. Każdy wywiad został poddany procesowi anonimizacji. Średni czas trwania wywiadu wynosił od 40 do 110 minut.

Analiza materiału empirycznego wskazuje, że wszyscy rodzice stosują „osobiste" strategie zaradcze mające na celu zaprzestanie picia przez ich uzależnione dzieci. Wywiady, w których rodzice wykorzystywali specyficzną strategię zaradczą, jaką jest wzbudzanie emocji samoświadomościowych, uczyniono przedmiotem szczegółowych analiz. Strategia ta wykorzystywana była dotychczas przez pięć matek i jednego ojca. Poniżej przedstawiono ogólną charakterystykę badanych osób.

25 Por. S. Gudkova, Wywiad w badaniach jakościowych, w: Badania jakościowe. Metody i narzędzia. t. 2, red. D. Jemielniak, Wydawnictwo Naukowe PWN, Warszawa 2012, s. 115-116. 
Tabela 1. Ogólna charakterystyka respondentów stosujących strategię mającą na celu zaprzestanie picia przez dorosłe dziecko, polegającą na wzbudzaniu emocji samoświadomościowych

\begin{tabular}{|l|l|l|l|l|}
\hline Lp. & Osoba badana & $\begin{array}{l}\text { Dziecko uzależnione } \\
\text { od alkoholu }\end{array}$ & $\begin{array}{l}\text { Miejsce zamieszkania } \\
\text { osoby badanej }\end{array}$ & $\begin{array}{l}\text { Miejsce zamieszkania } \\
\text { dorosłego dziecka }\end{array}$ \\
\hline N1 & matka & Syn & duże miasto & - \\
\hline N2 & matka & Syn & duże miasto & $\begin{array}{l}\text { w jednym domu } \\
\text { z rodzicem }\end{array}$ \\
\hline N3 & matka & córka & duże miasto & $\begin{array}{l}\text { w jednym domu } \\
\text { z rodzicem }\end{array}$ \\
\hline N4 & ojciec & Syn & duże miasto & $\begin{array}{l}\text { mieszka osobno ze swoją } \\
\text { rodziną }\end{array}$ \\
\hline N5 & matka & syn & wieś & $\begin{array}{l}\text { w jednym domu } \\
\text { z rodzicem }\end{array}$ \\
\hline N6 & matka & córka & duże miasto & $\begin{array}{l}\text { mieszka osobno } \\
\text { z przyjaciółmi }\end{array}$ \\
\hline
\end{tabular}

\section{Wyniki}

W przeprowadzonych badaniach wyłoniono wiele strategii zaradczych mających na celu zmianę zachowania uzależnionych dzieci. Rodzice dorosłych dzieci uzależnionych od alkoholu izolują je od czynników sprzyjających piciu, organizują minimalną stabilizację by zatrzymać degradację dziecka, tłumaczą, proszą, pilnują. Natomiast strategia polegająca na wzbudzaniu emocji samoświadomościowych (takich jak wstyd czy poczucie winy) zostanie szczegółowo omówiona w dalszej części artykułu.

W przeprowadzonych wywiadach zwraca uwagę fakt zawstydzania uzależnionych dzieci. Może ono bazować na odwoływaniu się do panujących norm społecznych, np.:

„Pamiętam, jechaliśmy właśnie tam, gdzie mama mieszka i..., na P. [ulica $w$ dużym mieście], patrzymy, on stoi, a wwojsku byt, $w$ Z. [mate miasto], [pauza] patrzymy, a on dzwoni..., bo te telefony takie byty, nie, na ulicach, on dzwoni z telefonu. Ja dochodzę do niego, mówię, a ty gdzie ty jesteś, mówie [pauza], a czemu ty tu jesteś, czy ktoś wie, że ty tu jesteś? No co to za wojsko, jak ty tu jesteś w Ł. [duże miasto], a stużysz... Oj, mama, mówi, my tylko tak na trochę wyszliśmy tego, nie... Ale już wypity byt. Ja mówię, czy ty nie piteś? No to później byt na przepustce to ja go się pytam, dlaczego ty [zawahanie] pijesz 
wódkę tam? O, mama, wysytaja nas w nocy po wódke [pauza] nad ranem, kiedy tylko. Tych młodych tak wysyłali, nie?" (N2)

W sytuacji przyłapania osoby na tym, że jej zachowanie jest niezgodne z przyjętymi zasadami czy celami, powinno pojawić się zażenowanie czy poczucie winy i chęć zadośćuczynienia. W powyższym cytacie nie powstają takie emocje, gdyż osoba zawstydzana przyczyny swojego zachowania lokuje na zewnątrz (przełożeni kazali).

Przyłapanie osoby na ,gorącym uczynku” ma także skłonić ją do zmiany zachowania (w tym wypadku zaprzestania picia) poprzez skonfrontowanie jej np. ze stratami finansowymi, jakie poniosła w związku z piciem;

„Dopiero się okazato, ile on pit, jak byty te porzadki takie generalne $w$ stodole, bo teraz tam nic nie trzymaja, [pauza] zwierzat, aby konie, no to [pauza] było tam robione, to dopiero się okazało jak on dużo... [pauza] To cztery worki chyba, takie od zboża, tych butelek byto. Mówię, patrz, [pauza] ile, mówię, za to byś coś sobie zrobit, coś kupit, patrz, ile to" (N5).

Taka konfrontacja okazuje się również mało skuteczna, gdyż:

„Ale on byt taki, że on [pauza] nic się nie odezwat. Jak mu się coś powiedziało, to on tylko głowe spuścit i nic" (N5).

Takie zachowanie osoby (zgodnie z teorią poznawczo-atrybucyjną) wskazuje na przeżywanie wstydu, który nie motywuje jednostki do zmiany.

Motywowanie poprzez odwoływanie się do zasobów osoby, kiedy nie są one uświadomione przez ich adresata, również okazuje się nieefektywnym działaniem.

„Ja potrafie jej mówić i teraz żeśmy z Piotrusiem tłumaczyli, mówili, [pauza] uwierz w siebie, damy sobie bez niego radę. Nie, nie damy, płakata, roztrzęsiona, ja nie chcę żyć, bo jego nie ma, bo sobie nie damy..., i w kótko będzie to powtarzała. (...) Ona już tak przesiąkta, wie Pani, tym ciagtym jego wmawianiem, że ona nie da sobie rady, że sobie nie poradzi, że..." (N3)

Często wykorzystywaną strategią jest zawstydzanie pijących dorosłych dzieci poprzez odwoływanie się do jakości wypełnianej roli rodzicielskiej. Jedni rodzice oczekują zmiany poprzez sam fakt posiadania dziecka: 
„(...), to wie Pani, a to, to, no teraz ma taki dodatkowy jeszcze, [zastanowienie] bo prze... bo już ta mała ma w listopadzie 5 lat będzie miała, ona już dużo rzeczy rozumie, wie Pani, jak,

jak [pauza] jak [zastanowienie] przyjdzie, powiedzmy, pod... podpity, bo to mu się niekiedy jeszcze zdarza, to [zastanowienie] rozmawiaja, tatuś śpi, ja mówię, no bo zmęczony jest, nie, nie, nie jest zmęczony, nie, nie. Wie Pani, to..."

Rozpoznaje?

„...to już, [zastanowienie] 5 lat, to już, to już nie..., no jest dziecko, ale, ale już dużo rzeczy rozumie, no. [pauza] I tak, tak to jest, no". [cmoknięcie] [westchnienie] (N4)

Inni odwołują się do uczuć żywionych przez dziecko wobec pijącego rodzica:

„Wnuczka, 4-letnie dziecko. Za co? Bo od taty śmierdzi. [pauza] I w poniedziatek, no, mówię, patrz, [pauza] czy ty się zastanowiłeś, mówię. O..., najpierw mu ta żona powiedziała, on nie dowierzat i ja weszłam, i mówię, no, że co, Ania, mówię, Ania nie chciała spać, mówię, o tu, i nie chcę..., i u mnie wymiotowała, i powiedziała, śmierdzi. Zastanów się [pauza] dla kogo ty żyjesz, dla kogo robisz. [pauza] (...) No a zwłaszcza, że kocha ta córkę swoja, [pauza] światu nie widzi, na glowe mu wejdzie. To jest..., jej wszystko wolno. (...)Ale teraz właśnie po tej komunii tego syna powiedział, że, o, nie, mówi, [pauza] mówi..., ja mówię, widzisz, nawet..., zastanów się, nawet twoja kochania córunia jak się po..., wypileś i nawet nie chce do ciebie, mówię, spała u mnie, wymiotowała, widzisz. Nie dowierzam, mówię, uwierz i zastanów się, czy masz dla kogo żyć i to. A on mówi, no chyba mam dla kogo życ" (N5).

Odwoływanie się do roli rodzicielskiej uzależnionego dorosłego dziecka zgodnie $z$ teorią poznawczo-atrybycyjną może wywołać poczucie winy i skłonić osobę do zmiany swojego zachowania czy zadośćuczynienia. Jednak nieudane próby „nie picia dla dziecka" potęgują poczucie winy i w konsekwencji mogą przerodzić się w uogólniony wstyd. 
„Ona bardzo byta za nim [pauza] od matości. Ona tylko u taty na kolanach przesiedziała. [pauza] A jak zacząt pić tak koniec". [westchnienie]

Trudno się dziwić, tak, że...

„No, no".

...nie zna, nie ufa, też się boi.

„Tak. A z tym jeszcze, jeszcze obiecat jej, że się już więcej nie napije, [pauza] a później pijany przyszedt. Ona se tak to ukodowata" (N2).

Podejmowane próby oddziaływania rodziców dorosłych dzieci uzależnionych od alkoholu, poprzez oddziaływania na emocje samoświadomościowe, wraz z pogłębianiem się procesu uzależnienia stają się nieskuteczne:

„Nie, nie! On już taki się zrobił..., już tak przepity jest, że on..., on już nie patrzy na nic. Czy kto patrzy, czy widzi, czy co. Już tera..., już teraz to i [zawahanie] awantur nie robi. [pauza] Już taki przepity" (N2).

„(...) a jak się z nia rozmawiać, jak tego, to ona już od dzisiaj nie będzie piła, już będzie wszystko dobrze, ona już wie, że już przetego..., tak $\dot{z}$ e ona będzie..., już nie będzie piła, no i co, odwraca się i robi swoje, i szuka ta..., takiego towarzystwa, gdzie będzie mogła wypić" (N6).

„Wszyscy mu tlumaczyli, wszyscy chcieli, żeby to po prostu ni..., i nie chciat. No to już kupowali później z mety, no i jak kupili wódkę, no tak po prostu z..., zatrut się alkoholem, po prostu zadusit się" (N1).

\section{Wnioski}

Strategia zaradcza odwołująca się do wzbudzania emocji samoświadaomościowych u pijących dorosłych dzieci wydaje się być strategią nieskuteczną. Najczęściej wzbudzanymi emocjami samoświadomościowymi przez rodziców wobec dzieci uzależnionych od alkoholu jest wstyd i poczucie winy. Choć celem rodziców (matek czy ojców) jest wywołanie zmiany zachowania, czyli zaprzestanie picia, mało kto z nich jest świadomy tego, że zarówno wstyd czy poczucie winy są emocjami, 
które mogą nasilać chęć picia. Wielu rodziców nie wie, że choroba alkoholowa to choroba emocji, że każde nieprzyjemne uczucie jest intensyfikowane na tyle, że chęć picia jest bardzo duża - wówczas osoba uzależniona pije, żeby nie czuć. W chorobie alkoholowej mówi się o mechanizmie nałogowego regulowania uczuć, odwołującym się do izolacji uczuciowej osoby uzależnionej od otoczenia, co wynika z przynoszenia sobie ulgi alkoholem ${ }^{26}$. Napięcie emocjonalne, które powstaje podczas doświadczania takich emocji jak zażenowanie, wstyd czy poczucie winy, zgodnie z hipotezą redukcji napięcia, jest dobrze redukowane przez działanie alkoholu. Warto także pamiętać, że alkohol wyraźnie osłabia reakcję na stres, tym samym zmniejsza reakcje będące jego skutkiem ${ }^{27}$.

Rodzice dorosłych dzieci uzależnionych od alkoholu różnią się między sobą poziomem wiedzy na temat uzależnienia ${ }^{28}$. Edukacja w tym obszarze zapewne pozwoli uniknąć stosowania nieskutecznych oddziaływań i może sprzyjać wypracowaniu pozytywnych sposób uczestnictwa w procesie zdrowienia swojego dziecka.

\section{Bibliografia}

Chodkiewicz J., Rola zasobów osobistych w utrzymaniu abstynencji przez mężczyzn uzależnionych od alkoholu, „Alkoholizm i Narkomania” 2001, tom 14, s. 277-287. Cierpiałkowska L., Ziarko M., Psychologia uzależnień-alkoholizm, Wydawnictwo Akademickie i Profesjonalne Spółka z o.o., Warszawa 2010.

Cur A., Szymona K., Domański M., Opolska A., Jojczuk M., Parentalalcoholabuse and eatingbehaviors in adolescents, „Polish Journal of Public Health” 2015, vol. 125(4), s. 194-196.

Dodziuk A., Wstyd, Instytut Psychologii Zdrowia, PTP, Warszawa 1999.

Gizer I. R., Ehlers C. L., Vietend C., Seaton-Smithe K. L., Feiler H. S., Lee J. V., Segall S. K., Gilder D. A., Wilhelmsen K. C., Linkagescan of alcoholdependence in the UCSF Family Alcoholism Study, „Drug and Alcohol Dependence” 2011, vol. 113, s. 125-132.

26 Por. R. Janowski, Uzależnienie od alkoholu, w: Uzależnienia w praktyce klinicznej. Zagadnienia diagnostyczne, red. B. Będkowska-Korpała, PARPAMEDIA, Warszawa 2009, s. 69.

27 Por. B. T., Woronowicz, Uzależnienia. Geneza, terapia, powrót do zdrowia, dz. cyt., s. 71.

28 Por. J. Orford, L. Templeton, A. Patel, A. Copello, R. Velleman, The 5-Step family intervention in primary car dz. cyt, s. 29. 
Gizer I. R., Seaton-Smithe K. L., Ehlers C. L., Vietend C., Wilhelmsen K. C., Heritability of MMPI-2 Scales in the UCSF Family AlcoholismStudy, ,Journal of AddictiveDiseases" 2010, vol. 29 (1), s. 84-97.

Gudkova S., Wywiad w badaniach jakościowych, w: Badania jakościowe. Metody i narzędzia.t. 2, red. D. Jemielniak Wydawnictwo Naukowe PWN, Warszawa 2012, s. 111-129.

Hałas E., Interakcjonizm symboliczny, PWN, Warszawa 2012.

Janowski R., Uzależnienie od alkoholu, w: Uzależnienia w praktyce klinicznej. Zagadnienia diagnostyczne, red. B. Będkowska-Korpała, PARPAMEDIA, Warszawa 2009, s. 59-76.

Knudson T. M., Terrell H. K., Codependency, Perceived Interparental Conflict, and Substance Abuse in the Family of Origin, „The American Journal of Family Therapy" 2012, vol. 40, s. 245-257.

Konecki K., Studia z metodologii badań jakościowych. Teoria ugruntowana, Wydawnictwo Naukowe PWN, Warszawa 2000.

Lewis M., Emocje samoświadomościowe: zażenowanie, duma, wstyd, poczucie winy, w: Psychologia emocji, red. M. Lewis, J. M. Haviland-Jones, GWP, Gdańsk 2005 s. 780-797.

Mellibruda J., Sobolewska-Mellibruda Z., Integracyjna psychoterapia uzależnień. Teoria i praktyka, Instytut Psychologii Zdrowia, Polskie Towarzystwo Psychologiczne, Warszawa 2006.

Mellibruda J., Strategiczno - strukturalna psychoterapia uzależnień, „Alkoholizm i Narkomania" 1997, nr 3, s. 307-324.

Orford J., Templeton L., Patel A., Copello A., Velleman R., The 5-Step family intervention in primary care: I. Strengths and limitations according to family members, ,Drugs: education, prevention and policy” 2007, vol. 14(1), s. 29-47.

Panaghi L., Ahmadabadi Z., Khosravi N., Sadeghi M.S., Madanipour A., Living with Addicted Men and Codependency: The Moderating Effect of Personality Traits, „Addict Health” 2016, vol. 8(2), s. 98-106.

Rubacha K., Metodologia badań nad edukacja, Wydawnictwa Akademickie i Profesjonalne, Warszawa 2008.

Seligman M. E. P., Optymizmu można się nauczyć. Jak zmienić swoje myślenie i swoje życie, Media Rodzina of Poznań, Poznań 1990.

Szczepanik R., Okólska K., Zapomniani rodzice (dorostych) dzieci uzależnionych od alkoholu, ,Alkoholizm i Narkomania” 2018, nr 31(4), s. 273-300.

Urbaniak-Zając D., Kos E., Badania jakościowe w pedagogice, Wydawnictwo Naukowe PWN, Warszawa 2013.

Woititz J. G., Matzeństwo na lodzie. Psychologiczne problemy żon alkoholików, IPZiT, Warszawa 1989. 
Woronowicz B. T., Uzależnienia. Geneza, terapia, powrót do zdrowia, Media Rodzina, PARPAMEDIA, Warszawa, Poznań 2009.

\title{
Agnieszka Jaros: Evoke self-conscious emotions as a strategy used by parents of adult children with alcohol problem to change their behavior
}

\begin{abstract}
Summary
The aim of this paper is to analyze one of the strategies used by parents to stop drinking alcohol in their adult children. This strategy is based on self-conscious emotions. In-depth interviews were conducted with parents of adult children with alcohol problem. Based on the analysis of interviews, it turned out that emotions such as shame and guilt are commonly used in the relations of parents with their adult drinking children. Shame and guilt are using to stopdrinking alcohol and compliance with social norms. However, not all self-conscious emotions cause changes in behavior.
\end{abstract}

Keywords: alcohol dependence, self-conscious emotions, shame, guilt, parents of adult children dependent on alcohol 